JOEAI (Journal of Education and Instruction)

Volume 2, Nomor 2, Desember 2019

e-ISSN : 2614-8617

p-ISSN : 2620-7346

DOI: https://doi.org/10.31539/joeai.v2i2.988

\title{
RELEVANSI RANAH KOGNITIF DAN MOTIVASI BERPRESTASI DENGAN HASIL BELAJAR PAI
}

\author{
Nurjannah \\ Institut Agama Islam Negeri Curup \\ nurjannahtaklim@gmail.com
}

\begin{abstract}
ABSTRAK
Tujuan penelitian ini adalah untuk mengetahui hubungan gaya kognitif dan gaya motivasi berprestasi dengan hasil belajar Pendidikan Agama Islam (PAI) siswa SMPN 5 Rejang Lebong. Metode penelitian menggunakan metode survey dengan pendekatan teknik korelasional. Data penelitian bersumber dari tes hasil gaya kognitif dan tes motivasi berprestasi serta hasil belajar PAI yang diperoleh dari nilai raport. Hasil penelitian menunjukkan tidak ada hubungan yang signifikan antara gaya kognitif dengan hasil belajar PAI dengan $\rho$-value 0,122 . Terdapat hubungan yang signifikan antara motivasi berprestasi dengan hasil belajar PAI dengan $\rho$-value 0,022 . Gaya kognitif dan motivasi berprestasi berhubungan dengan hasil belajar PAI $\rho$ value $=0,031>0,05$. Simpulan, tidak ada hubungan yang signifikan antara gaya kognitif dengan hasil belajar PAI. Terdapat hubungan yang signifikan antara motivasi berprestasi dengan hasil belajar PAI. Gaya kognitif dan motivasi berprestasi secara bersama-sama berhubungan dengan hasil belajar PAI siswa SMPN 5 Rejang Lebong.
\end{abstract}

Kata Kunci: Berprestasi, Hasil Belajar PAI, Kognitif, Motivasi

\begin{abstract}
The purpose of this study was to determine the relationship between cognitive style and achievement motivation style with the learning outcomes of Islamic Religious Education (PAI) students of SMP 5 Rejang Lebong. The research method uses survey methods with a correlational engineering approach. The research data were sourced from cognitive style test results and achievement motivation tests and PAI learning outcomes obtained from report cards. The results showed there was no significant relationship between cognitive style with PAI learning outcomes with $\rho$-value 0.122. There is a significant relationship between achievement motivation and PAI learning outcomes with $\rho$-value 0.022. Cognitive style and achievement motivation are related to PAI learning outcomes $\rho$ value $=0.031>0.05$. Conclusion, there is no significant relationship between cognitive style with PAI learning outcomes. There is a significant relationship between achievement motivation and PAI learning outcomes. Cognitive style and achievement motivation are jointly related to the learning outcomes of PAI students of Rejang Lebong Middle School.
\end{abstract}

Keywords: Achievement, PAI Learning Outcomes, Cognitive, Motivation 


\section{PENDAHULUAN}

Pembelajaran pendidikan agama Islam (PAI) adalah suatu upaya membelajarkan peserta didik agar dapat belajar, butuh belajar, terdorong belajar, mau belajar dan tertarik untuk terus menerus mempelajari agama Islam, baik untuk kepentingan mengetahui bagaimana cara beragama yang benar maupun mempelajari islam sebagai pengetahuan (Muhaimin, 2002). Tujuan pendidikan agama islam adalah membentuk kepribadian muslim yaitu suatu kepribadian yang seluruh aspeknya dijiwai oleh ajaran Islam (Zuhairini, et al, 1995).

Hasil pembelajaran pendidikan agama Islam dapat berupa hasil nyata (actual out-comes) dan hasil yang diinginkan (desired out-comes), actual outcomes adalah hasil belajar yang dicapai peserta didik secara nyata karena digunakannya suatu metode pembelajaran pendidikan agama Islam tertentu yang dikembangkan sesuai dengan kondisi yang ada. Sedangkan desired out-comes merupakan tujuan yang ingin dicapai yang biasanya sering mempengaruhi keputusan perancang pembelajaran pendidikan agama Islam dalam melakukan pilihan suatu metode pembelajaran yang paling baik untuk digunakan sesuai dengan kondisi pembelajaran yang ada. Hasil pembelajaran menurut Muhaimin, dapat diklasifikasikan menjadi keefektifan, efisiensi, dan daya tarik (Muhaimin, 2002).

Di samping perbedaan tiap individu, yang perlu diperhatikan dalam proses pembelajaran adalah variable kondisi pembelajaran. Reigeluht \& Merril (1979) dalam Rufi'i (2011) mengelompokkan variabel kondisi pembelajaran menjadi tiga kelompok, yaitu: (1) tujuan dan karakteristik bidang studi, (2) kendala dan karakteristik bidang studi, dan (3) karakteristik pebelajar. Karakteristik belajar adalah aspek-aspek atau kualitas perseorangan pembelajar, seperti bakat, minat, motivasi, orientasi tujuan, intelegensi, gaya kognitif, hasil belajar yang telah dimiliki dan lain-lain.

Gronlund mengelompokkan hasil belajar atas; (1)pengetahuan;(2) pemahaman; (3) keterampilan berpikir; (4) keterampilan dalam penampilan; (5) keterampilan berkomunikasi; (6) keterampilan berhitung; (7) keterampilan belajar sambil bekerja; (8) keterampilan bersosialisasi; (9) sikap; (10) minat; (11) apresiasi; dan (12) penyesuaian diri. (Gronlund, 1978). Sedangkan Bloom mengelompokkan hasil belajar atas tiga ranah, yaitu: (1) ranah kognitif; berhubungan dengan perubahan pengetahuan; (2) ranah afektif; berhubungan dengan perkembangan atau perubahan sikap sebagai hasil dari proses belajar, dan (3) ranah psikomotorik; berhubungan dengan penguasaan keterampilan motorik (Bloom, 1970).

Gaya kognitif adalah cara konsisten seseorang merespon dan menggunakan stimuli dalam lingkungan belajar. Konsep gaya kognitif timbul sebagai usaha-usaha dalam bidang psikologi perbedaan individu yang berkaitan dengan perbedaan tingkah laku kognitif manusia. Para peneliti menyelidiki konsep gaya kognitif untuk mengetahui bagaimana sesungguhnya pikiran itu 
berfungsi memproses informasi yang masuk, dan bagaimana pikiran dipengaruhi oleh persepsi seseorang. Penyelidikan tentang gaya kognitif adalah hasil usaha witkin, Halzmann, Gardner, kogan, messick dan rekan mereka. Kedudukan gaya kognitif dalam proses pembelajaran tidak dapat di abaikan. Hal ini sesuai dengan pandangan Reigeluth bahwa dalam variabel pembelajaran, gaya kognitif merupakan salah satu karakteristik peserta didik yang masuk dalam variabel kondisi pembelajaran, di samping karakteristik peserta didik lainnya seperti motivasi, sikap, bakat dan minat (Rowland, 1996).

Gaya kognitif sebagai sikap, kecenderungan atau strategi tabiat yang stabil yang mementukan gaya kebiasaan seseorang dalam menanggap, mengingat, berpikir, dan menyelesaikan masalah (Saracho, 1997). Selanjutnya ia mengemukakan beberapa jenis gaya kognitif yaitu : (1) Field Independent versus Field dependent yang mencerminkan suatu cara analisis seseorang dalam menghadapi alam sekitar, (2) gaya pembentukan konsep yang mencerminkan ciriciri individu dalam menggunkan suatu jenis rangsangan tertentu dan hubungannya sebagai asa untuk membentuk konsep, (3) keluasan katagori yang berhubungan dengan kecenderungan seseorang dalam menyusun katagori konsep secara luas atau sempit, (4) leveling versung sharpening sehubungan dengan perbedaan seseorang dalam pemerosesan ingatan, antara menyukai mengingat sesuatu dengan menyamakan terhadap hal-hal yang telah diingatnya atau membuat ciri baru dan menginatnya dalam ciri tersebut, (5) Scanning yang mencerminkan kecenderungan seseorang dalam memfokuskan perhatian pada suatu informasi (Salameh, 2011).

Dari beberapa definisi dan pengertian yang telah diuraikan dapat disimpulkan bahwa gaya kognitif adalah gaya dari tiap individu-individu yang sifatnya relatif stabil dan menjadi kebiasaan individu-individu tersebut dalam hal menerima mengingat, berpikir, dan menyelesaikan suatu masalah.

Motivasi dapat diartikan sebagai suatu proses psikologi yang mencerminkan interaksi antara sikap, kebutuhan, persepsi, dan keputusan yang terjadi pada diri sesorang. Proses psikologi timbul diakibatkan oleh faktor di dalam diri seseorang itu sendiri yang disebut intrinsic dan extrinsic. Faktor di dalam diri seseorang bisa berupa kepribadian , sikap, pengalaman dan pendidikan, atau berbagai harapan, cita-cita yang menjangkau ke masa depan sedang faktor dari luar diri dapat ditimbulkan oleh berbagi faktor-faktor lain yang sangat kompleks. Tetapi baik faktor ekstrinsik maupun faktor instrinsik motivasi timbul karena adanya rangsangan (Wahjosumidjo, 1984)

Motivasi dapat didefinisikan sebagai kekuatan, dorongan, kebutuhan yang rumit atau mekanisme memulai dan memelihara kegiatan untuk mencapai prestasi seseorang. (Miskel Cecil G, 1987) Sejalan dengan pengertian tersebut, motivasi dapat diartikan sebagai suatu dorongan dari dalam diri individu untuk memenuhi kebutuhan dalam mencapai tujuan yang diinginkan. 
Hicks \& Gullet, membedakan motivasi dalam dua kelompok yaitu motivasi internal dan motivasi eksternal. Motivasi internal adalah kebutuhan, keinginan dan harapan yang terdapat dalam pribadi seseorang yang menentukan berbagai pandangan, yang menurut giliran akan memimpin tingkah laku dalam situasi yang khusus. Sedangkan motivasi eksternal meliputi kekuatan yang ada di luar diri individu seperti halnya faktor pengendalian oleh manajer, juga meliputi hal-hal yang berkaitan dengan pekerjaan seperti gaji/upah, kondisi kerja, kebijaksanaan organisasi dan pekerjaan yang mengandung hal-hal penghargaan, pengembangan dan tanggung jawab.(1996)

Mengutip dari Teori Harapan Vroom (1964) yang mengembangkan sebuah teori motivasi berdasarkan jenis pilihan yang dibuat orang untuk mencapai tujuan, alih-alih berdasarkan kebutuhan internal. Teori harapan (expectancy theory) memiliki tiga asumsi pokok:1) setiap individu percaya bahwa bial ia berperilaku dengan cara tertentu ia akan memperoleh hal tententu. Ini disebut harapan hasil (outcome expectancy). 2) setiap hasil mempunyai nilai, atau daya tarik bagi orang tertentu. Ini disebut valensi (valence), 3) setiap hasil berkaitan dengan suatu persepsi mengenai seberapa sulit mencapai hasil tersebut. Ini disebut harapan usaha (effort expectancy). Motivasi orang dapat dijelaskan dari ketiga kombinasi ini bahwa: 1) suatu perilaku tertentu akan menghasilkan hasil tertentu, 2) hasil tertentu punya nilai positif baginya, 3) hasil tersebut dapat dicapai dengan usaha yang dilakukan seseorang. Jadi motivasi dalam teori harapan adalah keputusan untuk mencurahkan usaha (F. Faules, 2000)

Dari pemikiran yang telah dipaparkan di atas, aspek-aspek Gaya kognitif dan motivasi berprestasi di jadikan variabel independent dan hasil belajar merupakan variabel dependent.

Disisi lain penelitian yang berhubungan dengan relevansi ranah kognitif dan motivasi berprestasi dengan hasil belajar PAI juga dilakukan oleh Nurdin Ibrahim Universitas Teknologi Pendidikan FIP UNJ, Jl. Rawamangun Muka Jakarta Timur, yang bertujuan untuk mencari hubungan antara belajar mandiri dan motivasi berprestasi dengan hasil belajar pendidikan agama Islam, Penelitian ini dilaksanakan di SMP Terbuka, yang berinduk di SMP Negeri 55 Tanjung Priok, Jakarta Utara. Penelitian ini menggunakan metode survei pendekatan statistik dengan uji korelasi (Nurdin Ibrahim, 2010)

Selain itu penelitian tentang kecerdasan siswa pendidikan agama islam disekolah yang dilakukan oleh peneliti Atika Fitriani dan Eka yanuarti seorang dosen PAI di Institut Agama Islam Negeri Curup juga menjadi bahan pendukung bagi penelitian ini, dimana penelitian ini juga berhubungan dengan kecerdasan siswa tetapi lebih mengedepankan upaya guru pendidikan agama Islam dalam menumbuhkan kecerdasan spiritual siswa di Sekolah. Hasil penelitian ini menunjukkan bahwa: Upaya guru pendidikan agama Islam dalam menumbuhkan kecerdasan spiritual siswa di Sekolah dan dilaksanakan melalui beberapa cara: Menjadi teladan bagi siswanya, membantu siswa merumuskan misi hidup mereka, 
membaca Al-Qur`an bersama siswa dan dijelaskan maknanya dalam kehidupan, menceritakan pada siswa tentang kisah-kisah agung dari tokoh-tokoh spiritual, mengajak siswa berdiskusi dalam berbagai persoalan dengan perspektif ruhaniah, mengajak siswa kunjungan ke tempat-tempat orang yang menderita, melibatkan siswa dalam kegiatan keagamaan, mengajak siswa menikmati keindahan alam, mengikutsertakan siswa dalam kegiatan-kegiatan sosial, dan membentuk tim nasyit (Atika Fitriani \& Eka Yanuarti, 2018)

Berdasar hasil dari penelitian terdahulu maka dalam penelitian ini, peneliti memfokuskan untuk mengetahui relevansi ranah kognitif dan motivasi berprestasi dengan hasil belajar PAI pada. Pada dasarnya penelitian ini berupaya untuk mengetahui bagaimana hasil belajar PAI ditinjau dari kontribusi secara bersamasama gaya kognitif dan motivasi berprestasi. Penelitian ini juga berusaha untuk mengetahui kontribusi variabel gaya kognitif dan motivasi berprestasi terhadap hasil belajar PAI siswa SMPN 5 Rejang Lebong.

\section{METODE PENELITIAN}

Penelitian ini dilakukan pada peserta didik SMPN 05 Rejang Lebong. Sesuai dengan permasalahan yang diteliti dan tujuan penelitian yang ingin dicapai, penelitian bersifat verifikasi hipotesis menggunakan metode survei dengan pendekatan teknik korelasional. Hubungan antara variabel terikat dan variabelvariabel bebas penelitian ini dapat digambarkan dalam bentuk konstelasi hubungan antar variabel, seperti pada gambar 1 di bawah ini.

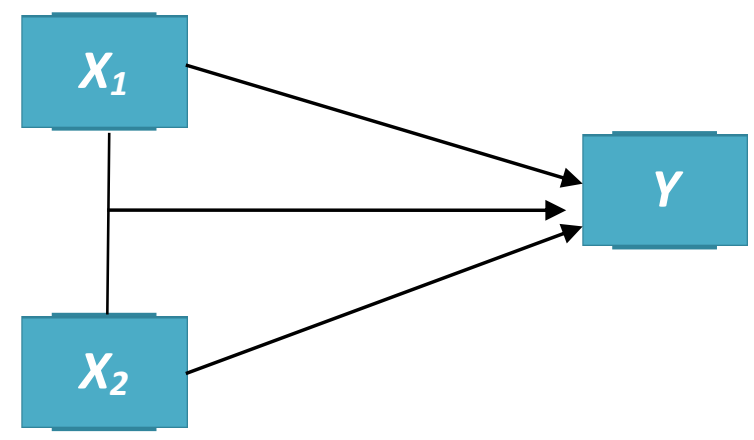

Gambar 1. Bagan Konstelasi Korelasional antara $X_{1}, X_{2}$ dengan $Y$

Keterangan :

$\mathrm{X}_{1}=$ Gaya Kognitif

$\mathrm{X}_{2}=$ Motivasi berprestasi

$\mathrm{Y}=$ Hasil belajar PAI

Populasi dalam penelitian ini adalah Peserta didik SMPN 5 Rejang Lebong. Teknik pengambilan sample menggunakan purporsif sampling. Yaitu menunjuk kelas XI APK 1 sebanyak 34 Peserta didik dengan alasan kelas ini merupakan kelas unggulan.

Instrument dalam penelitian ini menggunakan tes gaya kognitif dan motivasi berprestasi. Sebelum tes dilakukan terlebih dahulu diuji validitas dan 
reabilitas.

Dalam penelitian ini analisis data dilakukan dengan menggunakan statistik yaitu: Regresi sederhana dan jamak, korelasi sederhana, parsial, dan jamak semua pengukuran dilakukan pada taraf signifikansi $\alpha 0,05$. Sebelum dilakukan pengujian hipotesis penelitian, terlebih dahulu dilakukan uji persyaratan analisis meliputi uji normalitas dan uji homogenitas.

\section{HASIL DAN PEMBAHASAN}

\section{Uji Normalitas}

Tabel 1

Uji Normalitas One-Sample Kolmogorov-Smirnov Test

\begin{tabular}{|c|c|c|c|c|}
\hline & & $\begin{array}{c}\text { Hasil Belajar } \\
\text { PAI }\end{array}$ & Gaya Kognitif & $\begin{array}{c}\text { Motivasi } \\
\text { Berprestasi }\end{array}$ \\
\hline $\mathrm{N}$ & & 34 & 34 & 34 \\
\hline \multirow{2}{*}{ Normal Parameters } & Mean & 81.65 & 52.53 & 78.09 \\
\hline & Std. Deviation & 2.398 & 4.223 & 9.959 \\
\hline \multirow{3}{*}{ Most Extreme Differences } & Absolute & .136 & .103 & .184 \\
\hline & Positive & .136 & .088 & .072 \\
\hline & Negative & -.099 & -.103 & -.184 \\
\hline Kolmogorov-Smirnov Z & & .792 & .602 & 1.070 \\
\hline Asymp. Sig. (2-tailed) & & .558 & .862 & .202 \\
\hline \multicolumn{5}{|l|}{ a. Test distribution is Normal. } \\
\hline b. Calculated from data. & & & & \\
\hline
\end{tabular}

Berdasarkan hasil uji normalitas di bawah ini maka angka signifikansi uji asymp.Sig atau P. Value $>0,05$ atau 0,558 >0,05 (hasil belajar PAI), 0,862 > 0,05 (hasil gaya kognitif) dan 0,202 >0,05 (motivasi beprestasi) maka data menujukkan berdistribusi normal.

\section{Uji Linieritas}

Tujuan Uji linieritas adalah untuk mengetahui hubungan antara variebel bebas dan terikat linier atau tidak. Pengujian dilakukan dengan bantuan SPSS 21 for Windows. Criteria pengujian linieritas adalah jika nilai signifikansi Deviation From Linierity lebih besar 0,05 maka hubungan antara variabel bebas dan terikat adalah linier. Uji linieritas pertama adalah variabel Gaya kognitif $\left(\mathrm{X}_{1}\right)$ terhadap hasil belajar (Y). Hasil perhitungan keberartian dan linieritas tertera pada tabel 2:

Tabel 2

ANOVA Table Linieritas Regresi $X_{1}$

\begin{tabular}{|c|c|c|c|c|c|c|c|}
\hline & & & $\begin{array}{l}\text { Sum of } \\
\text { Squares }\end{array}$ & $\mathrm{df}$ & $\begin{array}{l}\text { Mean } \\
\text { Square }\end{array}$ & $\mathrm{F}$ & Sig. \\
\hline \multirow{5}{*}{$\begin{array}{l}\text { Hasil Belajar PAI } \\
* \text { Gaya Kognitif }\end{array}$} & \multirow{3}{*}{$\begin{array}{l}\text { Between } \\
\text { Groups }\end{array}$} & (Combined) & 80.298 & 15 & 5.353 & .880 & .594 \\
\hline & & Linearity & 13.873 & 1 & 13.873 & 2.281 & .148 \\
\hline & & $\begin{array}{l}\text { Deviation from } \\
\text { Linearity }\end{array}$ & 66.425 & 14 & 4.745 & .780 & .677 \\
\hline & \multicolumn{2}{|c|}{ Within Groups } & 109.467 & 18 & 6.081 & & \\
\hline & \multicolumn{2}{|l|}{ Total } & 189.765 & 33 & & & \\
\hline
\end{tabular}


Berdasarkan hasil pengujian pada tabel 2 dapat diinterpretasikan sig. dari Deviation from linierity adalah 0,677. Artinya ini lebih besar dari pada 0,05 $(0,677>0,05)$. Dengan demikian dapat disimpulkan bahwa hubungan antara Variabel $\mathrm{Y}$ dan Variabel $\mathrm{X} 1$ adalah linier. Uji linieritas yang kedua adalah motivasi berprestasi $\left(\mathrm{X}_{2}\right)$ terhadap hasil belajar $(\mathrm{Y})$. Hasil perhitungan keberartian dan linieritas tertera pada tabel 3:

Tabel 3

ANOVA Table Linieritas Regresi $\mathrm{X}_{2}$

\begin{tabular}{|c|c|c|c|c|c|c|c|}
\hline & & & $\begin{array}{l}\text { Sum of } \\
\text { Squares }\end{array}$ & Df & $\begin{array}{c}\text { Mean } \\
\text { Square }\end{array}$ & $\mathrm{F}$ & Sig. \\
\hline \multirow{5}{*}{$\begin{array}{l}\text { Hasil Belajar } \\
\text { PAI * } \\
\text { Motivasi } \\
\text { Berprestasi }\end{array}$} & \multirow[b]{3}{*}{$\begin{array}{l}\text { Between } \\
\text { Groups }\end{array}$} & (Combined) & 107.431 & 19 & 5.654 & .961 & .541 \\
\hline & & Linearity & 29.186 & 1 & 29.186 & 4.963 & .043 \\
\hline & & $\begin{array}{l}\text { Deviation } \\
\text { from } \\
\text { Linearity } \\
\end{array}$ & 78.246 & 18 & 4.347 & .739 & .730 \\
\hline & \multicolumn{2}{|c|}{ Within Groups } & 82.333 & 14 & 5.881 & & \\
\hline & \multicolumn{2}{|l|}{ Total } & 189.765 & 33 & & & \\
\hline
\end{tabular}

Berdasarkan hasil pengujian pada tabel 3 dapat diinterpretasikan sig. dari Deviation from linierity adalah 0,730. Artinya ini lebih besar dari pada 0,05 $(0,730>0,05)$. Dengan demikian dapat disimpulkan bahwa hubungan antara Variabel Y dan Variabel X2 adalah linier.

Uji linieritas yang ketiga adalah regresi ganda secara bersama-sama antara variabel Gaya kognitif $\left(\mathrm{X}_{1}\right)$ dan motivasi berprestasi $\left(\mathrm{X}_{2}\right)$ terhadap hasil belajar (Y). Selanjutnya dilakukan uji linieritas dan keberartian persamaan regresi menggunakan Uji multikorelasi (gejala multikollinieritas). Berdasarkan hasil pengujian pada tabel 4 di bawah ini dapat diinterpretasikan Nilai VIF=1,021. Artinya nilai VI F ini lebih kecil daripada $10 \quad(1,021<10)$. Dengan demikian tidak terjadi multikolinieritas diantara variabel bebas. Dengan demikian dapat disimpulkan bahwa hubungan antara Variabel $\mathrm{Y}$ dan Variabel X1, X2 adalah linier.

Tabel 4

Uji multikorelasi

\begin{tabular}{llcc}
\hline \multicolumn{3}{c}{ Coefficients $^{\mathbf{a}}$} \\
\hline \multirow{2}{*}{ Model } & \multicolumn{2}{c}{ Collinearity Statistics } \\
\cline { 2 - 4 } & & Tolerance & VIF \\
\hline \multirow{2}{*}{1} & Motivasi Berprestasi & .979 & 1.021 \\
\cline { 2 - 4 } & Gaya Kognitif & .979 & 1.021 \\
\hline \multicolumn{2}{l}{ a. Dependent Variable: Hasil Belajar PAI } & & \\
\hline
\end{tabular}

Selanjutnya dari persamaan regresi ganda tersebut dapat diinterpretasikan bahwa apabila dilihat secara bersama-sama hubungan Gaya Kognitif dan motivasi berprestasi dengan hasil belajar diukur dengan instrumen yang digunakan dalam 
penelitian ini, maka setiap kenaikan skor akan diikuti dengan kenaikan skor hasil belajar.

\section{Hubungan antara Gaya kognitif dengan Hasil Belajar}

Hipotesis pertama penelitian ini adalah terdapat hubungan positif antara Gaya Kognitif dengan hasil belajar. Pengujian hipotesis pertama dilakukan dengan menggunakan rumus korelasi Pearson Product Moment. Berdasarkan hasil perhitungan diperoleh koefisien korelasi antara Gaya kognitif $\left(\mathrm{X}_{1}\right)$ dengan hasil belajar $(\mathrm{Y}), \mathrm{r}_{\mathrm{y} 1}=0,27$. Angka ini mengisyaratkan bahwa hubungan antara Gaya kognitif dengan hasil belajar adalah negatif.

Dari hasil analisis berdasarkan tabel 5 di bawah ini diperoleh bahwa besarnya koefiensi korelasi sebesar 0,270 dengan $P$-Value 0,122 . Dengan jumlah responden sebanyak 34, maka $r$ tabel pada $\alpha=0,05$ sebesar 0,27 . Hal ini menunjukkan bahwa $r$ hitung sama dengan $r$ tabel $(0,27=0,27)$. Dengan demikian dapat disimpulkan bahwa koefisien koerelasi sebesar 0,27 adalah tidak signifikan. Sedangkan apabila menggunakan $P$-value, maka diperoleh koefisien sebesar 0,122. Karena $P$-Value lebih besar dari 0,05 bahkan 0,01 maka hal ini dinyatakan bahwa koefisien korelasi sebesar 0,27 tidak signifikan. Hasil ini memberikan makna bahwa tidak ada hubungan antara gaya kognitif dan hasil belajar PAI. Nilai $\mathrm{R}$ square sebesar 0,073 menunjukkan bahwa variabel gaya kognitif berkontibusi terhadap Hasil belajar PAI sebesar 1,73\%, sedangkan sisanya sebesar 92,7 \% dijelaskan oleh faktor lain yang tidak dianalisis dalam penelitian ini.

Tabel 5

Hasil Pengujian Keberartian Korelasi antara $X_{1}$ dengan $Y$

\begin{tabular}{|c|c|c|c|}
\hline \multicolumn{4}{|c|}{ Correlations } \\
\hline & & Gaya Kognitif & $\begin{array}{c}\text { Hasil Belajar } \\
\text { PAI }\end{array}$ \\
\hline \multirow{3}{*}{ Gaya Kognitif } & Pearson Correlation & 1 & .270 \\
\hline & Sig. (2-tailed) & & .122 \\
\hline & $\mathrm{N}$ & 34 & 34 \\
\hline \multirow{3}{*}{ Hasil Belajar PAI } & Pearson Correlation & .270 & 1 \\
\hline & Sig. (2-tailed) & .122 & \\
\hline & $\mathrm{N}$ & 34 & 34 \\
\hline \multicolumn{4}{|c|}{ Model Summary } \\
\hline Model & R Square & $\begin{array}{l}\text { Adjusted R } \\
\text { Square }\end{array}$ & $\begin{array}{l}\text { Std. Error of the } \\
\text { Estimate }\end{array}$ \\
\hline 1 & $.270^{\mathrm{a}}$ & .044 & 2.344 \\
\hline
\end{tabular}

\section{Hubungan antara Motivasi berprestasi dengan Hasil Belajar}

Hipotesis pertama penelitian ini adalah terdapat hubungan positif antara motivasi berprestasi dengan hasil belajar. Pengujian hipotesis kedua dilakukan dengan menggunakan rumus korelasi Pearson Product Moment. Berdasarkan hasil perhitungan diperoleh koefisien korelasi antara motivasi berprestasi $\left(\mathrm{X}_{2}\right)$ dengan hasil belajar $(\mathrm{Y}), \mathrm{r}_{\mathrm{y} 2}=0,392$. Angka ini mengisyaratkan bahwa hubungan 
antara motivasi berprestasi dengan hasil belajar adalah positif. Hasil perhitungan pengujian keberartian koefisien korelasi dengan menggunakan SPSS 21 tersebut tertera pada tabel pada tabel 6

Tabel 6

Hasil Pengujian Keberartian Korelasi antara $X_{2}$ dengan $Y$

\begin{tabular}{|c|c|c|c|}
\hline \multicolumn{4}{|c|}{ Correlations } \\
\hline & & Gaya Kognitif & $\begin{array}{c}\text { Hasil Belajar } \\
\text { PAI }\end{array}$ \\
\hline \multirow{3}{*}{ Hasil Belajar PAI } & Pearson Correlation & 1 & $.392 *$ \\
\hline & Sig. (2-tailed) & & .022 \\
\hline & $\mathrm{N}$ & 34 & 34 \\
\hline \multirow{3}{*}{$\begin{array}{l}\text { Motivasi } \\
\text { Berprestasi }\end{array}$} & Pearson Correlation & $.392 *$ & 1 \\
\hline & Sig. (2-tailed) & .022 & \\
\hline & $\mathrm{N}$ & 34 & 34 \\
\hline \multicolumn{4}{|c|}{ Model Summary } \\
\hline Model & R Square & $\begin{array}{c}\text { Adjusted R } \\
\text { Square }\end{array}$ & $\begin{array}{l}\text { Std. Error of the } \\
\text { Estimate }\end{array}$ \\
\hline 1 & $.392^{\mathrm{a}}$ & .127 & 2.240 \\
\hline
\end{tabular}

a. Predictors: (Constant), motivasi berprestasi

Dari hasil analisis diperoleh bahwa besarnya koefiensi korelasi sebesar 0,392 dengan P-Value 0,022. Dengan jumlah responden sebanyak 34, maka $\mathrm{r}$ tabel pada $\alpha=0,05$ sebesar 0,27 . Hal ini menunjukkan bahwa $r$ hitung sama dengan $r$ tabel $(0,392>0,27)$. Dengan demikian dapat disimpulkan bahwa koefisien koerelasi sebesar 0,2392 adalah signifikan. Sedangkan apabila menggunakan P-value, maka diperoleh koefisien sebesar 0,022. Karena P-Value lebih kecil dari 0,05 maka hal ini dinyatakan bahwa koefisien korelasi sebesar 0,392 signifikan. Hasil ini memberikan makna bahwa ada hubungan antara gaya kognitif dan hasil belajar PAI. Nilai R square sebesar 0,154 menunjukkan bahwa variabel motivasi berprestasi berkontibusi terhadap Hasil belajar PAI sebesar $15,4 \%$, sedangkan sisanya sebesar $84,6 \%$ dijelaskan oleh faktor lain yang tidak dianalisis dalam penelitian ini.

\section{Hubungan antara Gaya Kognitif dan motivasi berprestasi secara bersama- sama dengan Hasil Belajar}

Hipotesis ketiga penelitian ini adalah terdapat hubungan positif secara bersama-sama antara Gaya Kognitif dan motivasi berprestasi dengan hasil belajar. Pengujian hipotesis ketiga dilakukan dengan hasil analisis multivariate dengan regresi ganda Gaya kognitif dan motivasi berprestasi dengan hasil belajar PAI. Hasil statistik diketahui nilai korelasi $r$ hitung sebesar $r_{\mathrm{y} 3}=0,448$. Angka ini mengisyaratkan bahwa hubungan secara bersama-sama antara Gaya Kognitif dan motivasi berprestasi dengan hasil belajar adalah positif. Hasil perhitungan pengujian keberartian koefisien korelasi dengan menggunakan SPSS 21 tersebut tertera pada tabel 4.10 . 
Tabel 7

Hasil Pengujian Keberartian Korelasi antara $X_{1} X_{2}$ dengan $Y$

\begin{tabular}{|c|c|c|c|c|}
\hline \multicolumn{5}{|c|}{ Model Summary ${ }^{b}$} \\
\hline Model & $\mathrm{R}$ & R Square & Adjusted R Square & $\begin{array}{l}\text { Std. Error of the } \\
\text { Estimate }\end{array}$ \\
\hline 1 & $.448^{\mathrm{a}}$ & .200 & .149 & 2.212 \\
\hline
\end{tabular}

Tabel 8 ANOVA ${ }^{\mathrm{a}}$

\begin{tabular}{llrrrrr}
\hline Model & & Sum of Squares & df & Mean Square & F & \multicolumn{1}{c}{ Sig. } \\
\hline \multirow{2}{*}{1} & Regression & 38.040 & 2 & 19.020 & 3.886 & $.031^{\mathrm{b}}$ \\
\cline { 2 - 7 } & Residual & 151.725 & 31 & 4.894 & & \\
\cline { 2 - 7 } & Total & 189.765 & 33 & & & \\
\hline
\end{tabular}

a. Dependent Variable: Hasil Belajar PAI

b. Predictors: (Constant), Motivasi Berprestasi , Gaya Kognitif

Uji signifikansi koefisien korelasi diperoleh dari tabel Model Summary. Terlihat pada baris pertama koefisien korelasi $=0,448$ dan $\mathrm{F}_{\text {hitung }}\left(\mathrm{F}_{\text {change }}\right)=3,886$ dengan $\mathrm{p}$-value $=0,031>0,05$. Hal ini berarti $\mathrm{H}_{0}$ ditolak. $R$ Square merupakan koefisien Determinasi. Besarnya $\mathrm{R}$ Square adalah $\left(\mathrm{R}^{2}\right)$ adalah $0,2=20 \%$. Artinya besarnya pengaruh Gaya Kognitif dan motivasi berprestasi terhadap hasil belajar PAI $20 \%$ dan besarnya variabel lain yang mempengaruhi variable hasil belajar PAI adalah $80 \%$. Nilai R square sebesar 0,2 menunjukkan bahwa variabel Gaya kognitif dan motivasi berprestasi berkontibusi terhadap Hasil belajar PAI sebesar $20 \%$, sedangkan sisanya sebesar $80 \%$ dijelaskan oleh faktor lain yang tidak dianalisis dalam penelitian ini.

Menurut Bloom hasil belajar atas tiga ranah, yaitu: (1) ranah kognitif; berhubungan dengan perubahan pengetahuan; (2) ranah afektif; berhubungan dengan perkembangan atau perubahan sikap sebagai hasil dari proses belajar, dan (3) ranah psikomotorik; berhubungan dengan penguasaan keterampilan motorik.

Pada Penelitian ini mendiskripsikan dan menguji hubungan dari variabel terikat yaitu Gaya Kognitif dan motivasi berprestasi terhadap hasil belajar PAI. Teknik analisis yang digunakan adalah korelasi dan regresi ganda. Uji prasyarat yang harus dilakukan yaitu uji normalitas dengan menggunakan Uji kolmogorofsmirnov dan uji linieritas. Ketentuan dalam uji galat adalah bila asymp.Sig atau P. value $>0,05$, menujukkan data berdistribusi normal. Akan tetapi jika asymp.Sig atau $\mathrm{P}$. value $<0,05$ menunjukkan data tidak berdistribusi normal. Hasil perhitungan menunjukkan bahwa variabel independen Gaya kognitif mempunyai angka signifikansi uji asymp.Sig 0,862. Nilai tersebut $>0,05$. Variabel motivasi berprestasi mempunyai angka signifikansi uji asymp.Sig 0,202. Nilai tersebut > 0,05. Sedangkan Untuk variabel dependen hasil belajar PAI mempunyai angka signifikansi uji asymp.Sig 0,558. Nilai tersebut > 0,05. Dengan demikian bahwa variabel-variebl tersebut menujukkan berdistribusi normal.

Selanjutnya Uji prayarat analisis yang kedua dalam penelitian ini adalah uji linieritas. Pengujian dilakukan dengan bantuan SPSS. Kriteria pengujian 
linieritas adalah jika nilai signifikansi Deviation From Linierity lebih besar 0,05 maka hubungan antara variabel bebas dan terikat adalah linier. Uji linieritas pertama adalah variabel Gaya kognitif $\left(\mathrm{X}_{1}\right)$ terhadap hasil belajar $(\mathrm{Y})$. Hasil perhitungan keberartian dan linieritas Deviation from linierity adalah 0,677. Artinya ini lebih besar dari pada $0,05(0,677>0,05)$. Dengan demikian dapat disimpulkan bahwa hubungan antara Variabel $\mathrm{Y}$ dan Variabel $\mathrm{X} 1$ adalah linier. Uji linieritas yang kedua adalah motivasi berprestasi $\left(\mathrm{X}_{2}\right)$ terhadap hasil belajar (Y).

Hasil perhitungan keberartian dan linieritas berdasarkan hasil pengujian pada diinterpretasikan sig. dari Deviation from linierity adalah 0,730. Artinya ini lebih besar dari pada 0,05 (0,730>0,05). Dengan demikian dapat disimpulkan bahwa hubungan antara Variabel Y dan Variabel X2 adalah linier. Uji linieritas yang ketiga adalah regresi ganda secara bersama-sama antara variabel Gaya kognitif $\left(\mathrm{X}_{1}\right)$ dan motivasi berprestasi $\left(\mathrm{X}_{2}\right)$ terhadap hasil belajar $(\mathrm{Y})$. Selanjutnya dilakukan uji linieritas dan keberartian persamaan regresi menggunakan Uji multikorelasi (gejala multikollinieritas).

Hasil perhitungan Uji multikorelasi berdasarkan hasil pengujian pada tabel 4.5 dapat diinterpretasikan Nilai VIF=1,021. Artinya nilai VI F ini lebih kecil daripada $10 \quad(1,021<10)$. Dengan demikian tidak terjadi multikolinieritas diantara variabel bebas. Dengan demikian dapat disimpulkan bahwa hubungan antara Variabel Y dan Variabel X1, X2 adalah linier. Selanjutnya dari persamaan regresi ganda tersebut dapat diinterpretasikan bahwa apabila dilihat secara bersama-sama hubungan Gaya Kognitif dan motivasi berprestasi dengan hasil belajar diukur dengan instrumen yang digunakan dalam penelitian ini, maka setiap kenaikan skor akan diikuti dengan kenaikan skor hasil belajar.

Penelitian ini bertujuan untuk mengetahui dan menganalisis hubungan Gaya kognitif dan motivasi berprestasi dengan hasil belajar PAI Siswa kelas XI APK1 SMKN Kraksaan. Hasil belajar adalah kemampuan yang diperoleh peserta didik melalui proses belajar mengajar di sekolah dalam kurun waktu tertentu yang meliputi domain kognitif, afektif, dan psikomotorik yang dinyatakan dengan angka dan diukur dengan menggunakan tes hasil belajar. Hasil belajar yang dimiliki siswa menurut Gagne dipengaruhi oleh 3 tiga domain, yaitu: (1) domain kognitif; meliputi: pengetahuan, pemahaman, dan keterampilan berpikir, (2) domain afektif; meliputi: sikap, minat, apresiasi, dan penyesuaian diri, dan (3) domain psikomotorik; meliputi keterampilan dalam penampilan, keterampilan berkomunikasi, keterampilan berhitung, keterampilan belajar sambil bekerja, dan keterampilan dalam hubungan social. Pada penelitian ini akan menggali variabel Gaya kognitif dan motivasi berprestasi yang berhubungan dengan Hasil belajar.

Hipotesis pertama adalah dari hasil analisis dengan menggunakan korelasi Product Moment. Berdasarkan hasil perhitungan diperoleh koefisien korelasi antara Gaya kognitif $\left(\mathrm{X}_{1}\right)$ dengan hasil belajar $(\mathrm{Y}), \mathrm{r}_{\mathrm{y} 1}=0,27$ dengan $P$-Value 0,122 . Dengan jumlah responden sebanyak 34 , maka $r$ tabel pada $\alpha=0,05$ sebesar 
0,27 . Hal ini menunjukkan bahwa $r$ hitung sama dengan $r$ tabel $(0,27=0,27)$. Dengan demikian dapat disimpulkan bahwa koefisien koerelasi sebesar 0,27 adalah tidak signifikan. Sedangkan apabila menggunakan $P$-value, maka diperoleh koefisien sebesar 0,122. Karena $P$-Value lebih besar dari 0,05 bahkan 0,01 maka hal ini dinyatakan bahwa koefisien korelasi sebesar 0,27 tidak signifikan. Hasil ini memberikan makna bahwa tidak ada hubungan antara gaya kognitif dan hasil belajar PAI. Nilai R square sebesar 0,073 menunjukkan bahwa variabel gaya kognitif berkontibusi terhadap Hasil belajar PAI sebesar 1,73\%, sedangkan sisanya sebesar 92,7 \% dijelaskan oleh faktor lain yang tidak dianalisis dalam penelitian ini.

Hipotesis kedua menunjukkan bahwa terdapat hubungan yang positif dan signifikan antara motivasi berprestasi terhadap hasil belajar. Dari hasil analisis dengan menggunakan korelasi Product Moment diperoleh harga koefisien koefiensi korelasi sebesar 0,392 dengan P-Value 0,022. Dengan jumlah responden sebanyak 34, maka $r$ tabel pada $\alpha=0,05$ sebesar 0,27 . Hal ini menunjukkan bahwa $r$ hitung sama dengan $r$ tabel $(0,392>0,27)$. Dengan demikian dapat disimpulkan bahwa koefisien koerelasi sebesar 0,2392 adalah signifikan. Sedangkan apabila menggunakan P-value, maka diperoleh koefisien sebesar 0,022. Karena P-Value lebih kecil dari 0,05 maka hal ini dinyatakan bahwa koefisien korelasi sebesar 0,392 signifikan. Hasil ini memberikan makna bahwa ada hubungan antara gaya kognitif dan hasil belajar PAI.

Nilai R square sebesar 0,154 menunjukkan bahwa variabel motivasi berprestasi berkontibusi terhadap Hasil belajar PAI sebesar 15,4\%, sedangkan sisanya sebesar $84,6 \%$ dijelaskan oleh faktor lain yang tidak dianalisis dalam penelitian ini.

Hipotesis ketiga menunjukkan bahwa terdapat hubungan yang positif dan signifikan antara gaya kognitif dengan motivasi berprestasi secara bersama-sama terhadap hasil belajar PAI. Uji signifikansi koefisien korelasi diperoleh dari tabel Model Summary. Terlihat pada baris pertama koefisien korelasi $(=0,448$ dan $\mathrm{F}$ hitung $\left(\mathrm{F}_{\text {change }}\right)=3,886$ dengan p-value $=0,031>0,05$. Hal ini berarti $\mathrm{H}_{0}$ ditolak. $R$ Square merupakan koefisien Determinasi. Besarnya $\mathrm{R}$ Square adalah $\left(\mathrm{R}^{2}\right)$ adalah $0,2=20 \%$. Artinya besarnya pengaruh Gaya Kognitif dan motivasi berprestasi terhadap hasil belajar PAI $20 \%$ dan besarnya variabel lain yang mempengaruhi variable hasil belajar PAI adalah $80 \%$. Nilai R square sebesar 0,2 menunjukkan bahwa variabel Gaya kognitif dan motivasi berprestasi berkontibusi terhadap Hasil belajar PAI sebesar 20\%, sedangkan sisanya sebesar $80 \%$ dijelaskan oleh faktor lain yang tidak dianalisis dalam penelitian ini.

\section{SIMPULAN}

Berdasarkan hasil penelitian dan pembahasan pada Bab sebelumnya maka dapat diambil kesimpulan bahwa Tidak ada hubungan yang signifikan antara gaya kognitif dengan hasil belajar PAI, namun terdapat hubungan yang signifikan 
antara motivasi berprestasi dengan hasil belajar PAI. Adapun Gaya kognitif dan motivasi berprestasi berhubungan dengan hasil belajar PAI, yang berarti secara bersama-sama minat gaya kognitif dan motivasi berprestasi berhubungan dengan hasil belajar PAI siswa SMPN 5 Rejang Lebong.

\section{DAFTAR PUSTAKA}

Atika, F \& Eka, Y. (2018). Upaya Guru Pendidikan Agama Islam Dalam Menumbuhkan Kecerdasan Spiritual Siswa. Jurnal STAIN Curup 3(2).

Ghokhale, A. (2004). A Collaborative learning Enchaces Critical Thinking. [online] diakses dari (http//scholar.lib.vt.edu/journals/JTE/jte-v7n1/gokhle.jte-v7n1) tanggal 20 Maret 2019

Hamzah B. U. (2008). Teori Motivasi dan Pengukurannya, Analisis di Bidang Pendidikan. Jakarta: Bumi Aksara.

Hamzah, B. Uno. (2008). Teori Motivasi dan Pengukurannya, Analisis di Bidang Pendidikan, Jakarta: Bumi Aksara

Jujun S., S. (2015). Ilmu dalam perspektif sebuah kumpulan karangan tentang hakikat ilmu/ penyunting Jujun S, Suriasumantri. Jakarta: Yayasan Pustaka Obor Indonesia

Nurdin, I. (2010). Perspektif Pendidikan Terbuka Jarak Jauh; Kajian Teoritis dan Aplikasi. Jakarta. Bumi Aksara.

Saifuddin, A. (2007). Sikap Manusia, Teori dan Pengukurannya. Yogyakarta: Pustaka Pelajar

Salameh, E., M. (2011). Irrational Beliefs Among Jordanian collage Student and Relationship with self-confident. Asian Social Sains 7(2). [online] tersedia di http://www.ccsenet.org/ass di akses 19 Maret 2019

Salovey, Peter \& Sulyster. (1997). Emotional Develompment and Emotional Inteligence. New York: Basic Books

Saracho, O., N. (1997). Teachers' and Students' Cognitive Styles in Early Childhood Education. USA: Praeger.

Subhan. (2010). Pendidikan Agama Islam: Sebagai Transformasi Potensialitas ke Aktualitas, hal. 3. [online] di akses dari http://wonkeducationnetwork.blogspot.com/2007- /03/pendidikan-agama-islam.html 2010 (http://wonk-educationnetwork.blogspot.com- /2007/03/pendi-dikanagama-islam.html) tanggal 12 Maret 2019

Witkin, H., A. (1997). Field Dependent and Field Independent Cognitive Styles and Their Education Implication, New York : American Education Research Journal. Di akses dari https://www.jstor.org/stable/1169967. Tanggal 19 Maret 2019. 